\title{
8. Care in the wake of the financial crisis: gender implications in Spain and the United Kingdom
}

\author{
Blanca Deusdad, Jana Javornik, \\ Rosa Mas Giralt and Raquel Marbán-Flores
}

\section{INTRODUCTION}

Focusing on national provisions on care in Spain and the UK, this chapter explores government intervention and trajectories of policy change between 2008 and 2015, based on case studies developed in the course of the COST Action IS1102 SO.S. COHESION - Social services, welfare states and places. We examine whether and how care infrastructures support female employment and males' involvement in caregiving, considering the intersections of familistic dynamics in economically adverse circumstances from a gender perspective.

The selection of countries allows us to examine a combination of commonalities and differences. The two have very different welfare systems and trajectories, providing distinctive scenarios in which to study those issues. On the one hand, different histories and economies aside, both countries were significantly affected by the global financial crisis in 2008, during which they introduced austerity programmes and deficit management plans. The effects have been deeper in Spain, which continues to experience high rates of unemployment and slow economic recovery (Lin et al., 2013). By contrast, the UK returned to its pre-crisis economic levels by the second quarter of 2014 (O'Connor, 2015). On the other hand, the combination of changes introduced in parental leave and care systems provides a trajectory of significant interest for gender equality. While both countries show significant policy transformation in parental leave schemes to challenge gendered parenting, they vary in the amount of policy change introduced to provisions of care for children and older people. In Spain the long-term care system saw a significant overhaul, whereas in the UK gradual changes in this area have been taking place since the 1990s due to the political weight and lobbying influence of carers' organisations (e.g. Yeandle et al., 2012). 
In both countries government interventions show a trajectory towards more state support for care policies. However, austerity measures in response to the financial crisis have led to budget cuts, which negatively affect financing of policies and potentially widen inequalities in access. Such mixed dynamics in the care sector disrupt progress towards gender equality in practice, which negatively affects women's opportunity to continuously engage in the labour market and compete with men for the best paying jobs, and men's to actively engage in family care. With policies on care being central to the current reforms and transformation of the welfare states, policy programming around parental leave (used hereafter as an umbrella term for different types of child-related rights), childcare and care for older people is emblematic of interventions that cut across domains such as employment, children and care, gender and income.

Against this background, this chapter analyses policy change and the multilevel dynamics that shape policy provisions in these two European countries, to examine whether and how public support differently shapes women's and men's opportunities after they become parents. We argue that public policy provisions have gendered opportunity ramifications. Whilst care is a universal human need, it is embedded in the culture of social obligation that women are the primary carers (e.g. Anttonen and Zechner, 2011).

Comparative welfare state research highlights that welfare states differ in the extent to which they consider women's uneven capability to invest in paid employment and the family (e.g. Korpi, 2000; Leitner, 2003). Governments choose combinations of policy instruments, that is the services, the money to purchase services and/or familial care (Korpi, 2000), and these vary across countries. These choices represent the framework within which people and companies operate, making it easier/harder to be a carer in some countries than others. Public services are a necessary precondition for freeing women's time to participate in the labour market; if women remain locked into familial care obligations, they forgo an important source of (independent) income and self-realisation (EspingAndersen, 2009, p. 80). When both services and cash benefits are low, women's opportunities depend on their households' resources, namely access to the market, which exacerbates socioeconomic inequalities with gendered consequences. This opens up both the conceptual and analytical space for comparative analysis of recent policy developments. Using Javornik's (2014) analytical approach to comparative policy analysis we conceptualise these as publicly provided opportunity structures for carers, creating and constraining their possibilities to work and care. We focus on parental leave, childcare and care for older people as specific public policy 
instruments whose designs express multiple interpretations of gendered opportunities.

The chapter starts with a theoretical discussion to set the conceptual framework of the analysis. To identify and understand connections between current politics and policy developments, the next two sections flesh out 'the environment at the [austerity] time' (Page, 2006, p.92) in Spain and the UK. They present accounts of policy dynamics related to the economic difficulties between 2008 and 2015 through national policy trajectories. We conclude with a discussion of the insights learnt from these cases in relation to gender equality.

\section{THEORETICAL PERSPECTIVES}

Care has long been a 'woman-specific concept' (Daly and Lewis, 2000, p. 283). It has been firmly established in welfare state research that normative assumptions about gender roles underpin policies on care (Thane, 1991, p. 93); these may reinforce or challenge the conventional gender roles, both in terms of women's employment opportunities and men's involvement in care (e.g. Gornick and Meyers, 2003). As Wilson (1977, p. 9) reiterates, the welfare state is 'not just a set of services; it is also a set of ideas about society, about the family and - not least importantly, about women who have a centrally important role within the family, as its linchpin'.

Access to paid employment has conspicuous economic, political, cultural and social implications, for both personal autonomy and gender equality. However, women's access to independent income remains largely structured by widespread gendered division of caring, whereby women still bear the brunt of responsibility for care (Kröger and Yeandle, 2013). A growing body of comparative research on female employment has found that female employment rates generally drop subsequent to childbirth and that, in general, women who provide care are economically disadvantaged across countries (e.g. Gupta and Smith, 2001). The proportion of women withdrawing from paid employment and the size of their disadvantage over the life course, however, vary significantly across welfare states.

Public policies may either bolster or undermine women's early and continuous attachment to waged labour and men's active care, thus shaping carers' prospects for (adequate) income during their working lives and into retirement (Thane, 1991). Orloff (1993, pp. 303-4) argues that 'the character of public social provision affects women's material situations, shapes gender relationships, structures political conflict and participation, and contributes to the formation and mobilisation of specific identities and interests.' 
Nevertheless, welfare states differ in the extent to which they acknowledge the uneven capacity of primary carers (i.e. women) to invest in paid employment: whilst most assume that men and women equally need to earn for their own security, they do not necessarily assume equal care responsibilities (Pascall and Lewis, 2004, p. 391). States can provide a mix of policies coming from various public policy institutions, including time off from work (leave), the money for familial care, the services, and the money to purchase services (Korpi, 2000). Each represents different policy combinations, which differently constrain carers' choices, exacerbating socioeconomic and gender inequalities (e.g. Javornik, 2014).

To illustrate, parental leave may come with penalties, including discriminatory treatment in pay and promotion. Thus, for some, taking leave could be an option to fall back on instead of a first choice, especially when childcare services are limited (Javornik, 2014). Alternatively, welfare states may use leave policies to challenge the normative parenthood ideals (e.g. Leitner, 2003). Likewise, in the area of care for older people, cash transfers and allowances for family care may reinforce gendered roles. Women may prefer staying at home and this becomes the best option due to a lack of public funding for fostering entrance into the labour market. This suggests that government initiatives may transform gendered roles, which Javornik (2014) calls 'policy transformative potential', referring to the extent to which the state supports female employment over the life course and male involvement in care.

Using the gendered-magnifying glass, comparative welfare state research has developed conceptual and analytical tools to investigate how welfare states vary in the extent to which they reinforce or challenge gendered care (e.g. Leitner, 2003). They show that policies that regulate family responsibilities in care influence the choices and possibilities of women between work and care, and may have familistic or de-familistic effects (e.g. Leitner, 2003; Saraceno and Keck, 2011). Familistic welfare states promote and rely on family care, either explicitly (by financially investing in family care) or implicitly (by withdrawing any support to carers). By contrast, defamilistic policies facilitate carers' labour force participation and challenge gender-specific care, via public services, either the state or the market.

Leitner (2003) and Javornik (2014) show how each welfare state combines elements of both familialism and de-familialism, whereby familistic policies too could challenge gender roles when providing incentives to ensure that care provision is shared on equal terms among male and female family members' (Leitner, 2003, p. 367). Alternatively, whilst policies may enhance carers' employment, they could also 'threaten to recreate earlier forms of gender inequality in a new form' (Mandel and Semyonov, 2005, p. 951). What matters, then, is the overall policy constellation, which signals 
whether or not the state supports gender equality. From the gender equality perspective, what is particularly relevant is the extent to which policy acknowledges familial care, supports women's continuous employment and men's involvement in care, recognises and rewards care responsibilities and the changes therein. We argue that national statutory entitlements present material opportunities (resources) that shape the boundaries of what is possible and pave the way towards policy uptake. But multiple pressures and hurdles dictate carers' real possibilities to claim their statutory entitlements.

Against this background, we adapt Saraceno and Keck's (2011) and Javornik's (2014) analytical frameworks of de-familialism to evaluate changes in parental leave and services for children and older people in Spain and the UK. These policy areas were chosen because parental leave and childcare services form a 'package' available to parents following childbirth (Javornik, 2010; 2014). As families and populations age, care provisions for older people become relevant; together, then, 'care policies' determine women's and men's opportunities over their lives (Anttonen and Sipilä, 1996).

\section{CARE POLICIES, AUSTERITY AND GENDER EQUITY IN SPAIN AND THE UNITED KINGDOM}

This section turns to trends in parental leave and care for children and older people in Spain and the UK. As we will show, the two have very different welfare systems and trajectories, demonstrating significant policy transformation in parental leave schemes, but vary significantly in policy provision for children and older people.

\section{Spain}

Spain has been a latecomer to welfare state development and gender equality. Democracy brought about significant changes in women's rights and a new conception of the family and its values, which differed from those during Franco's regime (1939-75). When the social democratic party (PSOE) came to power in 1982, significant progress was achieved with the development and institutionalisation of social services. An important feature of the Spanish structure of social services is its decentralisation in Autonomous Communities (Comunidades Autónomas), which translates into diversity across different parts of the country. There is only one national state law on social and care services, namely the 2006 long-term care law for the promotion of personal autonomy and care for 
older and disabled people (Ley 39/2006 de Promoción de la Autonomía Personal y Atención a las personas en situación de dependencia, hereafter LAPAD).

In terms of gender equality, the most remarkable social policy transformations were introduced during President Zapatero's first term in office (2004-08), a period which saw the increasing influence of Spanish feminist lobbies (Comas d'Argemir, 2015). However, as will be explored below, the progressive policy trajectory initiated in this period was interrupted by the onset of the economic crisis and subsequent austerity measures and changes of government.

Women's caregiving position is closely related to the challenges that Spanish women face in the job market. In $2014,73.28$ per cent of part-time workers were women (UGT, 2015) and 62.5 per cent of women working part-time would have liked to work full-time (INE, 2014). In most cases, it seems, a part-time job is not a choice and women may be 'forced' to provide family care, given the high rates of unemployment and/or a lack of skills to enter/re-enter the job market. In addition, the gender pay gap increased with the recession, moving from 19.3 per cent in 2002 to 20.2 in 2014 (UGT, 2015). These circumstances, along with other impacts of the 2008 economic crisis, have strengthened intergenerational solidarity, including an 'exploitation' of family resources, whereby families increasingly rely on grandparents' pensions (or adult children being forced to move back home) as the only source of income for the whole family (Moreno, 2009; Deusdad et al., 2016).

The following sections will focus on those social policies that have improved gender equality conditions in relation to care in general, paying attention to representative policies in the area of parental leave, childcare and care for older people.

\section{Parental leave and childcare}

In Spain, it was not until 1986 with the consolidation of democracy that maternity leave was extended up to 16 weeks and paternity leave was recognised. Initially, fathers only had two days of leave after the birth of a child. The Gender Equality Act (Ley de Igualdad 35/2007), introduced to address gender discrimination, increased this allowance to fifteen days. In the proposal, paternity leave was to be offered for four weeks, but because of austerity measures this has been postponed until January 2017 (Escobedo et al., 2016). As of 16 December 2016, the government has proposed the reintroduction of the four-week optional paternity leave with a budgeted cost of EUR 400 million for 2017 (El Economista, 2016). Furthermore, although there is parental leave, only a few fathers use it (1.7 per cent in 2014; Escobedo et al., 2016). Although they recognise fathers' rights to 
care, these provisions do not go far enough in transforming traditional gendered parenting.

Another important achievement promoted by the Gender Equality Act was the 'birth benefit', known as 'baby cheque' (cheque bebé), providing an amount of EUR 2500 for every newborn child (initially introduced in 2007). To be eligible, one had to have Spanish nationality or have resided in Spain without interruption during the two previous years. In the case of single mothers, large families (three or more children) or children with disabilities, the cash transfer was EUR 3500. Nevertheless, this benefit was subject to criticism and was considered to be a populist measure. Furthermore, this lump-sum payment did not assist with long-term childcare needs nor could it be guaranteed that it was spent on the children. Eventually, it was abolished (in 2011) as the consequence of austerity cuts.

Parental leave and childcare are national policies, although regional differences exist also in parental leave in terms of benefits (Table 8.1). GDP expenditure for childcare is about 0.6 per cent, with an enrolment rate of 39.3 per cent for children under 3 years of age (above the averages of 29 per cent for the EU-27 and 32.6 per cent for the OECD), whilst the enrolment rate of 3-5-year-olds is 99.3 per cent (OECD, 2016). Such universal coverage has positively affected women's opportunity to participate in paid employment, but the effect was more positive for mothers with higher levels of education (Nollenberger and Rodríguez-Planas, 2011).

Childcare (0-3) is the responsibility of regional departments of education and thus the supply can vary between regions. For example, in the Basque Country, the enrolment rate was 51.3 per cent, in Extremadura 16.8 per cent and in The Canary Islands only 7.9 per cent (Síndic de Greuges, 2015). The average for the whole of Spain was 33.7 per cent, of which 17.2 per cent was public and 16.3 private (Síndic de Greuges, 2015). This proportion differs significantly between regions and municipalities and even between neighbourhoods, which affects inequalities in access. Private provision is higher in regions with more services, except for Murcia, where almost half of the services are private (7.9 per cent) with low enrolment rates (17.2 per cent) (Síndic de Greuges, 2015).

Private services are on average more expensive, which negatively affects service affordability and thus service accessibility. Access to state funding is means-tested and requires co-payments for the services provided, depending on the family's resources. This reinforces family care, largely by grandmothers, who often find themselves sandwiched between caring for grandchildren and their own parents or partners. Insufficient childcare provisions weaken women's position in the labour market, thus widening the gender opportunity gap (World Bank, 2014). 
Table 8.1 Changes in parental leave, Spain

\begin{tabular}{|c|c|c|}
\hline Type of leave & $2008-10$ & $2011-17$ \\
\hline $\begin{array}{l}\text { Statutory } \\
\text { maternity } \\
\text { leave }\end{array}$ & $\begin{array}{l}16 \text { weeks ( } 6 \text { weeks compulsory, } \\
\text { following birth). } \\
100 \% \text { of earnings (with a } \\
\text { ceiling). } \\
\text { A flat-rate benefit (EUR } 532.51 \\
\text { per month or EUR } 17.75 \\
\text { per day, for } 42 \text { days) to non- } \\
\text { eligible employed mothers. }\end{array}$ & $\begin{array}{l}\text { Remains in place. } \\
\text { Total earnings to a ceiling of } \\
\text { EUR } 3606.00 \text { a month in } \\
2015 \text { and EUR } 3642.00 \text { in } \\
2016 .\end{array}$ \\
\hline $\begin{array}{l}\text { Statutory } \\
\text { paternity leave } \\
\text { (father of the } \\
\text { child, spouse, } \\
\text { partner or } \\
\text { civil partner) }\end{array}$ & $\begin{array}{l}13 \text { days of paternity leave }+2 \\
\text { days of birth leave. } \\
100 \% \text { of earnings (with a } \\
\text { ceiling). } \\
\text { Some regions have improved } \\
\text { entitlements for public sector } \\
\text { employees. }\end{array}$ & $\begin{array}{l}\text { Extension of paternity leave } \\
\text { up to four weeks in } 2011 . \\
\text { Due to austerity measures } \\
\text { it was postponed until } \\
\text { January } 2017 .\end{array}$ \\
\hline Parental leave & $\begin{array}{l}\text { Individual right to } 12 \text { weeks } \\
\text { but the outstanding four } \\
\text { weeks have to be taken by } \\
\text { mothers. } \\
\text { Each parent is entitled to take } \\
\text { leave until three years after } \\
\text { childbirth. During the first } \\
\text { year, return to the same job } \\
\text { position is protected. } \\
\text { Seven regional governments } \\
\text { have introduced flat-rate } \\
\text { benefits: Navarre (2000); } \\
\text { Castile and León (2001); } \\
\text { Basque Country and } \\
\text { Castile-La Mancha (2002); } \\
\text { La Rioja (2003); Balearic } \\
\text { Islands and Murcia } \\
\text { (2008). }\end{array}$ & $\begin{array}{l}\text { Remains in place. } \\
\text { Regions in which flat rate } \\
\text { payments were abolished: } \\
\text { Murcia (2011); Castile } \\
\text { and León and Castilla-La } \\
\text { Mancha (2012); Navarre } \\
\text { (2013). } \\
\text { Regions in which flat rate } \\
\text { payments remain in place: } \\
\text { Basque Country (EUR } \\
\text { 271.25 per month in 2016); } \\
\text { La Rioja (EUR 250 per } \\
\text { month in 2016 to families } \\
\text { with an annual income } \\
\text { below EUR } 40000 \text { ). } \\
\text { Optional } 4 \text { weeks as of } 1 \\
\text { January } 2017 .\end{array}$ \\
\hline
\end{tabular}

Source: Authors' compilation based on Escobedo et al. (2016).

\section{Care for older people}

The Spanish long-term care law 39/2006 LAPAD is a key piece of legislation regulating care for older people, but also covering people with disabilities of all ages. It represents a significant improvement in the recognition of 
care needs and is an important achievement for gender equality (Deusdad, Lev et al., in this volume; Rodríguez-Cabrero and Marban-Gallego, 2013). As families (particularly women) are the main care providers, LAPAD helped to reduce the care burden of women, or, at least, to recognise and make their unpaid care work visible.

LAPAD was supposed to introduce new services (telecare, day centres, residential care and home care), as well as family care allowance (Prestación económica para cuidados en el entorno familiar). People applying for this allowance must first have their autonomy assessed. The assessment is first undertaken by a regional agency and then forwarded down to the social workers at the municipal level; these are in charge of implementing an individual care programme (Pla Individual de Atenció) for end-users. The way in which LAPAD has been implemented since 2007 has given priority to this allowance for family carers, even though it was initially considered as 'an exceptional measure' (Deusdad et al., 2016).

Social workers prioritise the allowance over other types of support because it is less costly for the administration and more easily accepted by the users. Furthermore, most carers are women in their fifties or sixties, and this allowance has been a source of income and social security contribution, which, in turn, provides the possibility of receiving a pension once they reach retirement age. This allowance has been key to recognising care as paid work, giving an economic value to activities traditionally carried out by women within the family. However, it has also reinforced women's role as family caregivers (Comas d'Argemir, 2015; CAP Deusdad, 2013). Overall, it improved somewhat the situation of women but has not radically transformed it.

The austerity cuts introduced by the Conservative Government since 2011 have further deteriorated gender equality. First, implementation of the allowance for people with the lowest level of autonomy was postponed until 2015; thus, people who were in need of care were left unattended, leaving care to the family, particularly women. Secondly, the maximum amount of monthly allowance for family caregivers has been reduced (from EUR 442.59 to EUR 387.64 after 2012). Thirdly, women who receive care allowance are no longer included in the social security system. Fourthly, the assessment criteria for determining one's level of autonomy have become stricter, as has the means-testing, which in some regions includes end users' property as well as income. Furthermore, the scarcity of resources and low to non-existent income have forced some men to become caregivers. That is, men have been forced by their personal family situation and financial needs to become caregivers and, in turn, to apply for the LAPAD allowance.

Overall, the effects of the austerity measures and policy changes intro- 
duced in response to the crisis have brought about important cutbacks in service delivery; this has had a detrimental effect on the rights previously acquired by family caregivers. The implementation of LAPAD brought about a hope of building a more universal welfare system by providing benefits that would meet citizens' care needs. However, in practice there remains a significant gap and unmet care needs of older adults in most of the regions; thus, care remains prevailingly a family responsibility, which most critically affects women.

\section{The United Kingdom}

This section presents an overview of policy processes between 2008 and 2015, focusing on UK-wide national provisions in parental leave, childcare and care for older people. This period covers two key changes of policy-making context: in 2010, a Conservative-led Coalition Government replaced the Labour Government; and in 2015, a Conservative Government took office. It also marks the launch of an austerity programme, a deficit reduction plan and a process of decentralisation to 'make public services more competitive', with significant local budgets cuts and welfare reforms (Ward, 2013). Our analysis also makes reference to key turning points in the past when a clear path dependency emerges.

In the UK's liberal welfare state, many aspects of work-care organisation are determined by employers. Legislation provides only minimum statutory entitlements, leaving any enhanced occupational packages to employers (for example, top-up payments over and above the statutory entitlements). This means that, in practice, the conditions under which women can access and engage with the labour market, but also men's access to caring over the family's lifecycle, differ between companies and sectors and can either exacerbate or reduce gender inequalities (e.g. Gornick and Meyers, 2003).

Childcare and parental leave are both national policies and apply across the UK as a whole. However, policy implementation has been a largely devolved responsibility since 1998 (Lloyd, 2015), with a more mixed policy landscape starting to develop under the 2010 (Conservative-led) Coalition and the 2015 Conservative Government, alongside ongoing fiscal constraints. The Coalition Government articulated a vision for challenging gendered care and boosting female employment by first extending paternity leave in 2011, followed by a policy redesign in 2014, when Shared parental leave was introduced. Plans to double free childcare for 'working families' were announced by the 2015 Conservative Government. This occurred in the context of increasing female employment and upward demand for childcare, but was accompanied with decentralisation, 
bringing along significant local budget cuts (Hastings et al., 2015). The Comprehensive Spending Review of 2010 set out an austerity programme and a 4-year deficit reduction plan, which significantly affected English local authorities (Ward, 2013). Significant income cuts created challenges in maintaining and extending care services for older people and children, leading to large-scale service re-planning. This is reflected in increasing user fees, co-payments for care services and in one of the most expensive childcare services in the OECD, with significant regional disparities (Javornik and Ingold, 2015). These developments occurred alongside an evolving national policy on ageing, an approach that predated both the financial crisis and the Coalition Government (Yeandle, 2016, p. 221). Overall, central funding of public services in England has been fundamentally restructured since 2010, with a differential impact in different parts of the country (Kispéter and Yeandle, 2015; Javornik and Ingold, 2015). Next we present these developments by policy areas.

\section{Parental leave and childcare}

The 2010 general election represents a critical juncture for distributing parenting responsibilities between parents. The Coalition Government first extended paternity leave and pay replacement, to allow fathers to take up to six months' leave during the child's first year, if the mother returned to work before the end of her maternity leave (Table 8.2). But soon, there appeared a stark contrast in the uptake of the short but paid paternity leave (91 per cent of fathers; Chanfreu et al., 2011) and the additional unpaid paternity leave. Failing to provide financial security, paternity leave was criticised for not challenging gender norms. To further address a relatively stubborn pattern of gendered parenting, and to advance women's employment, the same government introduced Shared parental leave (SPL) in 2014 (entered in force in April 2015). By taking a symbolic step towards explicitly promoting men's role in caring, this represents a milestone: by treating men as likely carers, it was introduced as a major advance for gender equality, enabling couples to distribute care more fairly (Table 8.2). The policy was initially put forward by the Liberal Democrats as a pre-2010 election pledge; but the final legislation significantly differs from the proposed, more flexible scheme, reflecting the response to the views expressed by the Conservatives (coalition partner), business, parents and child welfare organisations.

SPL creates a total of 52 shareable weeks available to eligible parents, 39 weeks of which are paid at the statutory rate (Table 8.2). Couples may switch from maternity leave to SPL after two weeks, which softens the distinction between maternity (pregnancy and childbirth) and parenthood (Javornik and Oliver, 2015). Both leave and pay are contingent upon 
Table 8.2 Changes in parental leave, United Kingdom

\begin{tabular}{|c|c|c|}
\hline Type of leave & Before 2015 & 2015-16 \\
\hline $\begin{array}{l}\text { Statutory } \\
\text { maternity leave/ } \\
\text { pay }\end{array}$ & $\begin{array}{l}52 \text { weeks: } 26 \text { of ordinary } \\
+26 \text { of additional leave } \\
+ \text { compulsory } 2 \text { weeks } \\
\text { following the birth, with } 39 \\
\text { weeks of statutory pay at } 90 \\
\text { per cent of woman's average } \\
\text { earnings for } 6 \text { weeks with no } \\
\text { ceiling + a flat-rate payment } \\
\text { of either GBP } 139.58 \text { or } 90 \\
\text { per cent of average gross } \\
\text { weekly earnings (whichever } \\
\text { is lower) for } 33 \text { weeks. The } \\
\text { remaining } 13 \text { weeks are } \\
\text { unpaid. }\end{array}$ & Remains in place. \\
\hline $\begin{array}{l}\text { Statutory } \\
\text { paternity leave/ } \\
\text { pay (father of } \\
\text { the child, spouse, } \\
\text { partner or civil } \\
\text { partner) }\end{array}$ & $\begin{array}{l}\text { Up to } 2 \text { weeks of statutory } \\
\text { paid leave. } \\
\text { Flat-rate payment of GBP } \\
139.58 \text { a week, or } 90 \text { per } \\
\text { cent of average weekly } \\
\text { earnings, if less. }\end{array}$ & Remains in place. \\
\hline $\begin{array}{l}\text { Additional } \\
\text { paternity leave }\end{array}$ & $\begin{array}{l}\text { In } 2011-15 \text {, possibility for } \\
\text { mothers to transfer part of } \\
\text { maternity leave (up to } 26 \\
\text { weeks) to the person taking } \\
\text { paternity leave } 20 \text { weeks } \\
\text { after the birth of the child. } \\
\text { Unpaid. }\end{array}$ & Abolished. \\
\hline $\begin{array}{l}\text { Parental leave/ } \\
\text { pay }\end{array}$ & $\begin{array}{l}18 \text { weeks' unpaid leave per } \\
\text { parent, per child (born or } \\
\text { adopted). Employees can } \\
\text { take it at any time up to the } \\
\text { child's } 18 \text { th birthday. To be } \\
\text { taken in blocks of a week } \\
\text { or multiples of a week, } \\
\text { unless the employer agrees } \\
\text { otherwise or the child is } \\
\text { disabled. Max. } 4 \text { weeks per } \\
\text { year. An employee remains } \\
\text { employed, with some terms } \\
\text { of the contract (contractual } \\
\text { notice and redundancy } \\
\text { terms) apply. }\end{array}$ & Remains in place (unpaid). \\
\hline
\end{tabular}


Table 8.2 (continued)

\begin{tabular}{|c|c|c|}
\hline Type of leave & Before 2015 & 2015-16 \\
\hline $\begin{array}{l}\text { Shared parental } \\
\text { leave/pay }\end{array}$ & & $\begin{array}{l}\text { Established on } 5 \text { April } 2015 . \\
\text { Qualifying mothers can end } \\
\text { maternity after } 2 \\
\text { compulsory weeks and } \\
\text { switch over to SPL; } 50 \\
\text { weeks can be shared } \\
\text { between the mother \& } \\
\text { father/other parent. The } \\
\text { father/other parent's right } \\
\text { to paternity leave remains } \\
\text { in place but is lost once } \\
\text { s/he takes SPL. } \\
\text { Pay is available for eligible } \\
\text { employees meeting } \\
\text { prescribed qualifying } \\
\text { requirements, paid at the } \\
\text { lesser between } 90 \text { per cent } \\
\text { of earnings and the flat } \\
\text { rate of GBP } 139.58 . \text { The } \\
\text { remaining } 13 \text { weeks of the } \\
\text { first year are unpaid. } \\
\text { To qualify, an individual } \\
\text { must meet a length of } \\
\text { service qualifying criterion, } \\
\text { a partner must meet an } \\
\text { economic activity test } \\
\text { (worked for } 26 \text { weeks out } \\
\text { of the } 66 \text { weeks before the } \\
\text { expected week of childbirth } \\
\text { and have earned at least } \\
\text { GBP } 30 \text { per week for } 13 \\
\text { weeks - min. GBP } 390 \text { in } \\
\text { total) plus the continuous } \\
\text { employment test; these } \\
\text { replicate those for paternity } \\
\text { leave/maternity allowance. }\end{array}$ \\
\hline
\end{tabular}

Source: Authors' compilation based on the Children and Families Act 2014, accessed December 2016 at http://www.legislation.gov.uk/ukpga/2014/6/pdfs/ukpga_20140006_ en.pdf and ACAS, accessed December 2016 at http://www.acas.org.uk/. 
maternity leave, and any time/pay taken as maternity leave gets subtracted from the total.

From the gender equality perspective, this policy is flawed for different reasons. First, it is grafted onto the existing framework of maternity leave. Because the Government failed to create a stand-alone right, it merely allows parents to split the existing maternity leave. Secondly, the state failed to introduce a forceful structure that provides sustainable statutory replacement pay levels. Instead, it provides modest statutory pay and leaves the decision about any enhanced packages to employers. Not mandating equivalent schemes for mothers and fathers is problematic because fathers' use of parental leave is significantly influenced by the benefit level. A clear line between the civil service and commercial employers has emerged over the past year, with the former more often offering enhanced options. No official data on uptake will be available before 2018, when the policy will be evaluated, but thus far, many employers have seen no business reasons to offer anything beyond statutory obligations; as a consequence, and in contrast to the policy aim, couples who choose to share leave are few. Overall, this new scheme has so far failed to enshrine gender equality as a societal ideal (Javornik and Oliver, 2015).

By contrast, two distinct factors define the childcare policy area: (1) a disconnect between childcare and other social welfare policy approaches; and (2) the strong impact of a political focus on market operations as the delivery model for childcare services. There is a continuing split concerning responsibilities for childcare at the level of central government; service provision has been a largely devolved responsibility since 1998 (Lloyd, 2015). This results in an array of actors operating across sectors; a complex and expensive funding mechanism with fees set by providers to maximise profitability lead to prohibitively high parental fee costs and chronic shortage of public childcare services. Namely, childcare is offered by a mix of private for-profit and not-for-profit childcare businesses, operating within a mixed market economy.

The UK appears a generous spender on childcare and early education (1.1 per cent of GDP in 2011; OECD, 2016). This is largely due to the demand-priming approach, where parents are reimbursed through the tax and benefit systems for services purchased in the open market (provided by private, voluntary and not-for-profit organisations and local council services), although such support is limited. Such a model challenges service affordability, and thus hardly enables mothers as primary carers to work (Brewer et al., 2014).

This has been a growing concern ever since the Labour Government introduced the universal 'early years' provision in 1998, equating it to 15 hours of care per week for 3- and 4-year-olds for 38 weeks a year (Javornik 
and Ingold, 2015). However, such limited free childcare conflicts with the reality of parents' working lives and with the tax/benefits system, which only recognises employment of 16 hours or more. The increase in casualised work means that it has become even more difficult for families to organise care arrangements, with time required to travel between childcare and places of work often being a hidden factor.

Despite efforts to remedy the childcare crisis over successive governments there is significant unmet need among parents, especially among the poorest and most disadvantaged, and parents with disabled children and those living in rural/remote areas. With recently reduced Working Tax Credit from 80 to 70 per cent, alongside decentralisation and local budget cuts, such disparity is likely to become more pronounced. Namely, facing increased childcare demand and not coping with the scale of cuts, many local authorities imposed additional charges; for instance, fees increased by 33 per cent for a child under 2 (Family and Childcare Trust, 2015). As childcare costs operate in the same way as a reduction in female wages, this may exacerbate gender inequality (Javornik, 2010).

The Coalition Government announced new plans in 2013 for a tax-free replacement for the existing employer-provided voucher system starting in 2015 (HM Treasury, 2014). Families would receive 20 per cent of yearly childcare costs, up to GBP 10000 per child; to be eligible both parents need to be in work, each earning less than GBP 150000 per year and not receiving support for childcare costs from tax credits or Universal Credit. From 2016 the childcare costs covered under Universal Credit were planned to increase to cover 85 per cent of eligible childcare. However, subject to the cap on social spending, this has now been rescheduled for autumn 2017 and it is unclear how it would be financed over time (Javornik and Ingold, 2015). The Coalition and Conservative Governments have done this at the expense of childcare provision for the most disadvantaged children: in 2010, they discontinued central funding for 'Sure Start' children's centres, which resulted in many centres closing down, cutting provision or raising fees (Kispéter and Yeandle, 2015, p. 109). This runs counter to the social mobility policy ideas reflected in the expansion of childcare and the social justice rationale underpinning investment in services and infrastructure (Lloyd, 2015).

Alongside these developments, the Conservative Government forged ahead with its pre-election pledge to double the current 15 hours per week of free childcare to 30 hours, to get more women into work. However, there are concerns over the sector's capacity to expand and the quality of such scaled-up provision (McLean, 2015). Moreover, state-funded support is tied to being in work. This suggests that the government sees childcare largely as a support strategy for employed parents. But for 
parents, particularly mothers in education, training, seeking a job or starting a business, having quality childcare in place is essential before they can undertake these activities (Ingold and Javornik, 2015). Families with young children seem to have borne the brunt of the welfare policy changes under the Coalition (Stewart and Obolenskaya, 2015). But if the government is assuming equal economic participation of men and women, then limiting access to affordable childcare will further intensify segregation between parents.

\section{Care for older people}

The provision of public services for older people is the statutory obligation of local authorities, and the system varies significantly across the country. Despite fundamentally restructuring central government funding of English local authorities in 2010, these duties have not been reduced (Kispéter and Yeandle, 2015, p. 107). Moreover, demand for local services has grown through a combination of demographic changes, higher unemployment and cuts in social insurance benefits, all resulting in a differential impact on the ability of local authorities to provide public services.

In England, the role of unpaid carers has been recognised in the system, largely due to the voluntary sector carer organisations (Yeandle, 2016, p. 226). Actually, the UK was one of the first countries to address the needs of carers of older people (Yeandle and Cass, 2013). The process began in the 1960s, and the Coalition Government included priorities to support carers in the 2010 National Carers' Strategy. This led to three main types of public support for carers:

1. The Carer's Allowance, which is a national cash welfare benefit administered outside local authority systems, available to people with low income who care for at least 35 hours per week for a person receiving certain disability benefits. These are intended to help towards higher costs incurred by carers of people with disability. Carers are entitled to claim Carer's Allowance when earning up to GBP 110 per week, so some carers are able to retain a part-time job. But as many cannot manage the burden of full-time care and part-time work, they are dependent on Carer's Allowance (Citizens' Advice, 2015, p. 3).

2. Local services designed to support carers comprise in-kind services provided by some local authorities, often following a Carer's Assessment, and include information, advice, training and respite care (at home or in a care home).

3. Legislated employment rights to flexible working and unpaid leave (Kröger and Yeandle, 2013); and, from 2010, the protection from being discriminated against in the workplace because of the care they 
provide to a disabled person (Yeandle and Joynes, 2012, p. 825). The right to request flexible working represents the key policy change affecting carers of older people, in addition to emergency time off (unpaid leave) to address caring emergencies.

Since 2010, public resources have increasingly focused on those with greatest needs: public spending on home care for older people has reduced by a fifth between 2010/11 and 2013/14, with 15 per cent fewer older people getting support (Mortimer and Green, 2015, p. 5). Spending on meals on wheels has halved in the last three years and approaching two-thirds fewer older people now receive them. A similar pattern can be seen regarding daycare (including day centres).

Studies show that a rebalancing is needed between the core, public and private economy in care provision (e.g. Mortimer and Green, 2015). Because of a mixture of spending cuts and rising demands, service provision is considered inadequate. In the coming years, the ability of the public economy to provide adequate support for those who cannot afford to pay for care may have to be compromised in terms of quantity and quality (Penny, 2012). As with childcare, those most adversely affected will be those without access to private care.

To address this issue, the Care Act was introduced in 2014. While this represents a significant change in social care law, it applies only to England (National Audit Office, 2014). In a nutshell, the act aims to explicitly shift responsibility to the local authorities (through a duty to ensure people's well-being), introduce the right to request a personal budget, and provide preventative services that could reduce or delay one's need for care. The law entered into force in April 2015, but there will be a lengthy settling-down period, with the final arrangements for the funding of care (including the cap on one's care costs) to be in place only in 2020 (originally announced for 2016). As only some of its aspects have come into force, it is premature to draw any conclusions about its effects. However, with its introduction, local councils were expected to undertake about half a million extra assessments; the new rights for carers are also very likely to put more pressure on public resources, which, as considered above, have been considerably reduced since 2010 .

Overall, provision across the different policy areas under New Labour, the Coalition and the Conservatives has been piecemeal; the complexity of subsidies, combined with inadequate quality monitoring, has resulted in patchwork arrangements, largely not suited to families' needs and with worse consequences for those in disadvantaged economic situations. Cuts to social benefits and public services will disproportionately affect women as unpaid but also as paid carers themselves. They are also likely to disrupt 
the support offered by extended families and friends, and thus affect women indirectly. Namely, this involves more women helping adult children/grandchildren, and women are more likely to increase unpaid help, to make up for the deficit from the public purse.

\section{DISCUSSION}

Focusing only on care in Spain and the UK, this chapter explored government interventions and trajectories of policy change from 2008 and until 2015. It investigated the dynamics in this sector from a gender perspective in economically adverse circumstances.

We found an increased policy interest in this area, with both countries explicitly seeking ways to address gendered care provision. This was to a large extent the function of national governments seeking to improve female employment, which represents a significant shift away from the male-breadwinner family model in both countries. To do so, and despite their different welfare systems and histories, they both introduced new leave legislation (still awaiting full implementation in the case of Spain), which could significantly reform gendered care by supporting more active fatherhood. By contrast, changes to childcare and care for older people have been mixed. Here too several acts/laws have recently come into force, but evidence was provided that budget cuts and marketisation risks are deepening in care both for children and older people. Interventions in both countries, especially after 2010 , seem to lack a strategic and sustainable approach to support gender equality in care, and have instead exacerbated socioeconomic and gender inequalities.

Ongoing fiscal constraints post-2008 seem to have halted the initial vision in both countries, disrupting the 'policy transformative potential' and reinforcing instead gendered care with familistic dynamics. These similar dynamics are remarkable given the different histories and welfare traditions of the two countries, and thus it is worth considering how different welfare contexts, diverging paths post-financial crisis and disparate political agendas have resulted in similar gendered dynamics. Each country started from different positions in terms of the provisions for carers and a gender division of care pre-crisis, and despite new policies, they continue to offer contrasting levels of public support (for example, parental leave being more developed in the UK). The governments that initially opted for gender equality principles in care policies in both countries were of left ideologies (i.e. the 2000s' Socialist government in Spain and 1990s' Labour in the UK). Subsequent moves to the centre and right of the political spectrum, intersecting with the effects of the economic crisis, led to a near 
complete halt of the gender equality push in Spain while, in the UK, it led to a dilution of more ambitious ideas. This dynamic of 'disrupted equality policy trajectories' coincides with Conservative cabinet ministers' commitment to austerity in both countries, using the crisis discourse to justify cutbacks. In Spain, however, the persisting effects of the economic crisis in terms of high unemployment rates may have reinforced the return to family (gendered) care dynamics as families navigate a precarious financial climate. In the UK, despite a recovered economy, the austerity ideology has continued to be used to justify cuts in the public sector, with detrimental impacts on local authorities' ability to provide care services for older people and childcare.

Overall a lack of sufficient benefits and cash transfers for care at national levels maintains the brunt of care tasks in the family and, as a result, adds further responsibility on to women. This has significant consequences for gender equality, as women's opportunities to access independent income are skewed. Both cases exemplify how the 'policy transformative potential' cannot be realised without adequate resourcing and complementing policies. It has been established that service unavailability and unaffordability alongside unsustainable benefits or pay replacements undermine gender equality, both in terms of women's employment opportunities and men's involvement in care. The situation of scarcity has re-established family intergenerational solidarity, particularly in the case of Spain. However, research covering a longer time period is required to show exactly how recent interventions will play out for different populations.

\section{REFERENCES}

Anttonen, A. and J. Sipilä (1996), 'European social care services: is it possible to identify models?', Journal of European Social Policy, 6 (2), 87-100.

Anttonen, A. and M. Zechner (2011), 'Theorizing care and care work', in B. PfauEffinger and T. Rostgaard (eds), Care Between Work and Welfare in European Societies, London: Palgrave Macmillan, pp. 15-34.

Brewer, M., S. Cattan, C. Crawford and B. Rabe (2014), 'The impact of free, universal pre-school education on maternal labour supply', Colchester: Institute for Social and Economic Research.

Chanfreu, J., S. Gowland, Z. Lancaster, E. Poole, S. Tipping and M. Toomse-Smith (2011), 'Maternity and paternity rights and Women Returners Survey 2009/10', Research Report No. 777, Sheffield: Department for Work and Pensions Research Report, accessed 16 January 2016 at http://goo.gl/OqGGHK.

Citizens Advice (2015), 'The role of carer's allowance in supporting unpaid care', London: Citizens Advice, accessed 12 August 2016 at www.citizensadvice.org.uk.

Comas d'Argemir, D. (2015), 'Los cuidados de larga duración y el cuarto pilar del sistema de bienestar', Revista de Antropología Social, 24, 375-404. 
Daly, M. and J. Lewis (2000), 'The concept of social care and the analysis of contemporary welfare states', British Journal of Sociology, 51 (2), 281-98.

Deusdad, B. (2013), 'Regulatory trajectory and current organisational framework of social services and social care', COST Action IS1102 Working paper, no. 1, accessed 10 January at http://www.cost-is1102-cohesion.unirc.it/docs/workingpapers/wg1.spain-catalonia-social-services-b.deusdad.pdf.

Deusdad, B., D. Comas d'Argemir and S. Dziegielewski (2016), 'Restructuring long-term care in Spain: the impact of the economic crisis on social policies and social work practice', Journal of Social Service Research, 42 (2), 246-62.

El Economista (2016), 'El permiso de paternidad en España pasará de dos a cuatro semanas en 2017', accessed 16 December 2016 at http://www.eleconomista.es/ economia/noticias/8030711/12/16/El-permiso-de-paternidad-se-ampliara-a-unmes-a-partir-de-enero.html.

Escobedo, A., G. Meil and I. Lapuerta (2016), 'Spain country note', in A. Koslowski, S. Blum and P. Moss (eds), International Review of Leave Policies and Research 2016, accessed 8 January 2016 at: http://www.leavenetwork.org/ lp_and_r_reports/.

Esping-Andersen, G. (2009), The Incomplete Revolution. Adapting to Women's New Roles, Cambridge: Polity Press.

Family and Childcare Trust (2015), 'Childcare costs survey 2014', accessed 20 April 2016 at http://www.familyandchildcaretrust.org/childcare-cost-survey-2015.

Gornick, C.J. and K.M. Meyers (2003), Families that Work. Policies for Reconciling Parenthood and Employment, New York: Russell Sage Foundation.

Gupta, N.D. and N. Smith (2001), Children and Career Interruptions: The Family Gap in Denmark, Bonn: Institute for the Study of Labor (IZA).

Hastings, A., N. Bailey, G. Bramley, M. Gannon and D. Watkins (2015), The Cost of the Cuts: The Impact on Local Government and Poorer Communities, York: Joseph Rowntree Foundation.

HM Treasury (2014), Budget 2014 (HC1104), London: House of Commons.

INE (National Institute of Statistics) (2014), 'Participación de los trabajadores a tiempo parcial y con contrato temporal', accessed 5 January 2016 at http://www. ine.es $/$ dynt3/inebase/index.htm?padre $=2128 \&$ capsel $=2415$.

Ingold, J. and J. Javornik(2015), 'Focusingfreechildcare on "working parents" is shortsighted', The Conversation, 22 July, accessed 15 January 2016 at https://theconver sation.com/focusing-free-childcare-on-working-parents-is-short-sighted-44623.

Javornik, J. (2010), Exploring Maternal Employment in Post-Socialist Countries: Understanding the Implications of Childcare Policies, PhD Thesis, Southampton: University of Southampton.

Javornik, J. (2014), 'Measuring state de-familialism: contesting post-socialist exceptionalism', Journal of European Social Policy, 24 (3), 240-57.

Javornik, J. and J. Ingold (2015), 'A childcare system fit for the future?', in L. Foster, A. Brunton, C. Deeming and T. Haux (eds), In Defence of Welfare 2, Bristol: Policy Press, pp. 75-8.

Javornik, J. and L. Oliver (2015), 'Legal battles loom on shared parental leave from fathers not getting equal benefits', The Conversation, 14 December, accessed 8 January 2016 at https://goo.gl/BYunIE.

Kispéter, E. and S. Yeandle (2015), 'Local welfare policies in a centralized governance system: childcare and eldercare in a period of rapid change in Leeds', in D. Kutsar and M. Kuronen (eds), Local Welfare Policymaking in European Cities, Cham: Springer International Publishing, pp. 101-16. 
Korpi, W. (2000), 'Faces of inequality: gender, class, and patterns of inequalities in different types of welfare states', Social Politics, 7 (2), 127-91.

Kröger, T. and S. Yeandle (2013), Combining Paid Work and Family Care, Bristol: Policy Press.

Leitner, S. (2003), 'Varieties of familialism. The caring function of the family in comparative perspective', European Societies, 5 (4), 353-75.

Lin, C.Y.-Y., L. Edvinsson, J. Chen and T. Beding (2013), 'Impact of the 2008 global financial crisis', in C.Y.-Y. Lin, L. Edvinsson, J. Chen and T. Beding (eds), National Intellectual Capital and the Financial Crisis in Greece, Italy, Portugal, and Spain, New York: Springer, pp. 5-15.

Lloyd, E. (2015), 'Early childhood education and care policy in England under the Coalition Government', London Review of Education, 13 (2), 144-56.

Mandel, H. and M. Semyonov (2005), 'Family policies, wage structures, and gender gaps: sources of earnings inequality in 20 countries', American Sociological Review, 70 (6), 949-67.

McLean, A. (2015), 'Promising more free nursery care is one thing, delivering it is quite another', The Conversation, 1 May, accessed 15 January 2016 at https:// theconversation.com/promising-more-free-nursery-care-is-one-thing-deliveringit-is-quite-another-41105.

Moreno, L. (2009), Reformas de las Politicas del Bienestar en España, Madrid: Siglo XXI.

Mortimer, J. and M. Green (2015), Briefing: The Health and Care of Older People in England 2015, London: Age UK.

National Audit Office (2014), Adult Social Care in England: Overview, London: National Audit Office.

Nollenberger, N. and N. Rodríguez-Planas (2011), 'Child care, maternal employment and persistence: a natural experiment from Spain', Discussion paper no. 5888, Bonn: Institute for the Study of Labor (IZA).

O'Connor, S. (2015), 'UK economy returns to pre-crisis level', Financial Times, accessed 8 January 2016 at http://www.ft.com/cms/s/0/bad33d56-13d5-11e48485-00144feabdc0.html\#axzz3vjNPR0k2.

OECD (2016), OECD Family Database, accessed 8 August 2016 at www.oecd.org/ social/family/database.htm.

Orloff, A.S. (1993), 'Gender and the social rights of citizenship: the comparative analysis of gender relations and welfare states', American Sociological Review, 58 (3), 303-28.

Page, S.E. (2006), 'Path dependence', Quarterly Journal of Political Science, 1 (1), 87-115.

Pascall, G. and J. Lewis (2004), 'Emerging gender regimes and policies for gender equality in a wider Europe', Journal of Social Policy, 33 (3), 373-94.

Penny, J. (2012), 'Coproduction and the core economy: a solution to care in crisis', The Nef Blog, accessed 8 January 2016 at http://www.neweconomics.org/blog/ entry/coproduction-and-the-core-economy-a-solution-to-care-in-crisis.

Rodríguez-Cabrero, G. and V. Marban-Gallego (2013), 'La atención a la dependencia en una perspectiva europea de la asistencialización a la quasi-universalización', in E. del Pino and M.A. Rubio (eds), Los Estados del Bienestar en la Encrucijada: Políticas Sociales en Perspectiva Comparada, Madrid: Tecnos, pp. 337-61.

Saraceno, S. and W. Keck (2011), 'Towards an integrated approach for the analysis of gender equity in policies supporting paid work and care responsibilities', Demographic Research, 25 (11), 371-406. 
Síndic de Greuges de Catalunya (2015), Informe sobre la Igualdad de Oportunidades en la Educación Infantil ( $0-3$ años), Barcelona: Síndic de Greuges, accessed 8 August 2016 at http://www.sindic.cat/site/unitFiles/3904/Informe\%20escolaritza cio $\% 200 \_3 \% 20$ anys_cast_ok.pdf.

Stewart, K. and P. Obolenskaya (2015), 'The coalition's record on the under fives: policy, spending and outcomes 2010-2015', Working Paper No. 12, London: STIRCED \& LSE, accessed 10 August 2016 at: http://sticerd.lse.ac.uk/dps/case/ spcc/wp12.pdf.

Thane, P. (1991), 'Visions of gender in the making of the British welfare state: the case of women in the British Labour party and social policy, 1906-1945', in G. Bock and P. Thane (eds), Maternity and Gender Policies, New York: Routledge, pp. 93-118.

UGT (2015), 'Trabaja igual, cobra igual y concilia igual', Madrid: UGT, accessed 5 January 2016 at: http://www.ugt.es/Publicaciones/Informe_8_\%20de_ Marzo_2015_UGT_Mujer_Trabajadora.pdf.

Ward, M. (2013), Public Services North: Time for a New Deal?, London: The Smith Institute.

Wilson, E. (1977), Women and the Welfare State, London: Tavistock.

World Bank (2014), 'Gender at work. A companion to the World Development Report on Jobs', accessed 16 January 2017 at http://documents.worldbank.org/curated/ en/884131468332686103/pdf/892730WP0Box3800report0Feb-02002014.pdf.

Yeandle, S. (2016), 'From provider to enabler of care? Reconfiguring local authority support for older people and carers in Leeds, 2008-2013', Journal of Social Service Research, 42 (2), 218-32.

Yeandle, S. and B. Cass (2013), 'Working carers of older people: steps towards securing adequate support in Australia and England?', in T. Kröger and S. Yeandle (eds), Combining Paid Work and Family Care. Policies and Experiences in International Perspective, Bristol: Policy Press.

Yeandle, S. and V. Joynes (2012), 'Challenges in combining work and care: evidence from investigating women's work in Leeds', Local Economy, 27 (8), 816-30.

Yeandle, S., T. Kröger and B. Cass (2012), 'Voice and choice for users and carers? Developments in patterns of care for older people in Australia, England and Finland', Journal of European Social Policy, 22 (4), 432-45. 
Blanca Deusdad, Jana Javornik, Rosa Mas Giralt, and Raquel Marbán-Flores - 9781786432117 Downloaded from PubFactory at 04/26/2023 10:45:53AM 